\title{
GAMBARAN DISIPLIN DAN PRESTASI KERJA TERHADAP PROMOSI JABATAN KARYAWAN HRD PT. TELKOM INDONESIA BANDUNG
}

\author{
Yoga Pranamulya \\ Universitas Pendidikan Indonesia \\ yoga.pranamulya@student.upi.edu \\ Hari Mulyadi \\ Universitas Pendidikan Indonesia \\ harimulyadi@upi.edu \\ Ridwan Purnama \\ Universitas Pendidikan Indonesia \\ ridwanpurnama@upi.edu
}

\begin{abstract}
ABSTRAK
Tujuan - Tujuan penelitian ini adalah untuk mengetahui gambaran disiplin, prestasi kerja dan promosi jabatan. Desain/metodologi/pendekatan - Desain penelitian ini adalah cross sectional. Penelitian ini menggunakan pendekatan deskriptif dengan metode explanatory survei. Unit analisis karyawan sebanyak 96 responden. Sebuah angket digunakan sebagai instrumen penelitian untuk mengumpulkan data dari responden. Teknik analisis yang digunakan adalah teknik deskriptif dengan menggunakan distribusi frekuensi.

Temuan - Berdasarkan hasil penelitian mneggunakan analisis deskriptif, didapatkan hasil bahwa disiplin kerja berada dalam kategori cukup sesuai dengan skor 75,4\%, prestasi kerja dalam kategori tinggi dengan skor 76,9\% dan promosi kerja berada dalam kategori tinggi dengan skor 77,9\%.

Orisinalitas/nilai - Penelitian ini memberikan pemahaman mendasar bagi isu-isu disiplin kerja, prestasi kerja dan promosi jabatan. Perbedaan penelitian ini dengan penelitian sebelumnya adalah objek penelitian yang dikaji berada pada sektor jasa, teori serta referensi yang digunakan adalah teori-teori terbaru.
\end{abstract}

Kata Kunci: Disiplin, Prestasi Kerja, Promosi Jabatan

Jenis Artikel: Studi Kasus

ABSTRACT

Purpose - The purpose of this study is to know the description of discipline, job performance and promotion positions.

Design/methodology/approachh - The design of this study was cross sectional. This research uses descriptive approach with explanatory survey method. An employee analysis unit of 96 respondents. A questionnaire was used as a research instrument to collect data from respondents. The analysis technique used is descriptive technique by using frequency distribution.

Findings - Based on the results of the research using descriptive analysis, the results showed that the work discipline is in the category quite appropriate with the score of $75.4 \%$, job performance in high category with score $76.9 \%$ and job promotion in the high category with score $77.9 \%$.

Originality/value - This research provides a fundamental understanding for issues of work discipline, job performance and promotion. The difference of this research with the previous research is the object of research that is studied in service sector, theory and reference used are the latest theories.

Keywords: discipline, job performance, promotion positions

Article Type : Case Study 


\section{PENDAHULUAN}

Pengembangan Sumber Daya Manusia merupakan cara organisasi agar dapat mempertahankan eksistensi kerja semua komponen organisasi. Sebuah organisasi harus mampu mengoptimalkan kemampuan sumber daya manusia yang dimilikinya agar pencapaian sasaran dapat terlaksana, namun hal tersebut tidaklah sederhana perlu pemahaman yang baik tentang organisasi, perlu ada strategi pengembangan yang matang agar Sumber Daya Manusia yang dimiliki sebuah organisasi terpakai sesuai kebutuhan (Ahmad, Iqbal, \& Sheeraz, 2015). Persaingan yang ketat membuat setiap organisasi berusaha menjaga dan mengembangkan Sumber Daya Manusia yang dimilikinya secara terus menerus. Setiap organisasi dituntut untuk selalu dapat menjaga pegawainya agar dapat menampilkan kinerja yang baik dan memelihara pegawainya agar dapat mendedikasikan diri kepada organisasi tempat di mana pegawai bekerja. Tanpa adanya unsur manusia dalam organisasi, tidak mungkin organisasi tersebut dapat mencapai tujuan yang diinginkan. Keberhasilan sebuah organisasi dalam mencapai tujuan salah satunya ditentukan oleh kinerja pegawainya (Masharyono 2015:813).

Pengembangan Sumber Daya Manusia diartikan sebagai penyiapan individu-individu untuk memikul tanggung jawab yang berbeda atau lebih tinggi di dalam organisasi, biasanya berkaitan dengan peningkatan kemampuan intelektual untuk melaksanakan pekerjaan yang lebih baik. Pengembangan mengarahkan pada kesempatankesempatan belajar yang didesain guna membantu pengembangan para pekerja, sehingga menghasilkan Sumber Daya Manusia yang berkualitas untuk mencapai suksesi posisi yang dijalani selama kariernya (Sutrisno 2010:62).

Keberadaan manusia sebagai sumber daya manusia adalah sangat penting dalam organisasi karena sumber daya manusia menunjang organsiasi melalui karya, bakat, kreativitas, dorongan dan peran nyata seperti yang dapat dilihat dalam setiap organisasi. Tanpa adanya unsur manusia dalam sebuah organisasi dimana keberhasilan dalam mencapai tujuan organisasi sangat ditentukan oleh kinerja karyawannya (Senen 2015:94).

Peran kepemimpinan dalam suatu organisasi atau perusahaan merupakan peranan yang sangat penting. Majunya suatu organisasi atau perusahaan tergantung dari pemimpin dalam perusahaan tersebut. Seorang pemimpin adalah pemegang kendali dan pengambil keputusan oleh karenanya gaya kepemimpinan seseorang sangat mempengaruhi pencapaian kinerja dan tujuan perusahaan (Senen \& wahyuni 2016:59). Setiap perusahaan mempunyai tujuan yang harus dicapai. Tujuan tersebut dapat tercapai dengan bantuan sumber daya manusia yang baik. Sumber daya manusia akan membantu perusahaan dalam mencapai tujuan yang telah direncanakan, maka perusahaan perlu memberikan pengarahan kepada karyawannya (Senen \& Widyanata 2016:47). Sumber daya manusia tidak bisa dipandang mudah. Pegawai yang dimiliki organisasi harus memiliki rasa kepemilikan terhadap organisasi tempatnya bekerja. Selain rasa memiliki, sikap dan loyalitas pegawai terhadap organisasi berpengaruh terhadap dedikasi pegawai dalam melaksanakan tugas dan tanggung jawabnya. dedikasi tinggi serta loyalitas yang kuat dari pegawai akan menimbulkan komitmen pegawai terhadap organisasi (Tarmedi \& Sumiyati 2016:92).

Memunculkan Sumber Daya Manusia yang berkualitas adalah dengan promosi jabatan. Adanya promosi jabatan diharapkan dapat membuat Sumber Daya Manusia yang ada di dalam organisasi atau perusahaan mampu menunjukan kemampuan terbaiknya, karena promosi jabatan juga merupakan rangsangan dan dorongan bagi mereka untuk berlomba dalam memberikan kemampuan terbaik yang dimilikinya. Setiap pegawai yang memiliki prestasi kerja yang tinggi, menginginkan promosi jabatan, karena promosi jabatan dipandang sebagai pengakuan prestasi kerja yang mereka berikan kepada organsiasi, sehingga pegawai termotivasi untuk bekerja, karena merasa pekerjaannya di hargai dan diakui oleh organisasi (Saydam dan Kadarisman 2012:133). Keberhasilan individu dalam mengerjakan tugasnya yang bisa terlihat dari segi dimensi keterikatan, keahlian merencanakan, daya usaha dalam pekerjaan dan prestasi secara keseluruhan (Martoyo 2010: 115).

Rendahnya promosi jabatan karyawan menjadi masalah multidimensi utama yang dihadapi perusahaan di berbagai sektor pada banyak Negara, baik yang bergerak di sektor publik maupun swasta, dalam lembaga-lembaga kesehatan, pendidikan, perbankan, perusahaanperusahaan milik Negara, hingga perusahaanperusahaan kecil, sehingga memaksimalkan kinerja pegawai menjadi tantangan utama bagi setiap organisasi agar dapat memanfaatkan sumber daya yang ada secara lebih efisien dan efektif guna mempertahankan daya saing. (Esther, Muoria 2011; Ng'ang'a, Robert 2013; Nickson lumwagi et al., 2014; Imhmed , Abdullah Elhamaly, 2014; Nadeem Iqbal et al, 2013; Goddy Osa, 2014; Sheehan, Maura, 2014).

Pentingnya promosi jabatan sangat berpengaruh besar untuk menumbuhkan kinerja karyawan yang lebih baik, hal ini menjadi motivasi yang paling efektif selain kenaikan gaji (Muhamad Ehsan Malik, Noor Muhamad 2014). Pengadaan (procurement) promosi jabatan karyawan yang baik bagi perusahaan akan lebih mudah. Sebaliknya, jika kesempatan untuk dipromosikan 
relatif kecil atau tidak ada, maka gairah kerja, semangat kerja, disiplin kerja, dan prestasi kerja karyawan akan menurun (kwenin, Nzulwa \& Mustapha 2015: 13).

Faktor yang mempengaruhi disiplin kerja menurut (Muchadarsyah Sinungan 2013:32) yaitu : (1) Absensi; yakni pendataan kehadiran pegawai yang sekaligus merupakan alat untuk melihat sejauh mana pegawai itu mematuhi peraturan yang berlaku dalam perusahaan. (2) Sikap dan Perilaku; yakni tingkat penyesuaian diri seorang pegawai dalam melaksanakan semua tugas-tugas dari atasannya. (3) Tanggung Jawab; yakni hasil atau konsekuensi seorang pegawai atas tugas-tugas yang diserahkan kepadanya.

Sedangkan menurut (Sutrisno 2010:152) mengatakan pengukuran prestasi kerja diarahkan pada enam aspek yang merupakan bidang prestasi kunci bagi organisasi, yaitu: (1) Hasil kerja. Tingkat kuantitas maupun kualitas yang telah dihasilkan dan sejauh mana pengawasan dilakukan. (2) Pengetahuan pekerjaan. Tingkat pengetahuan yang terkait dengan tugas pekerjaan yang akan berpengaruh langsung terhadap kuantitas dan kualitas dari hasil kerja. (3) Inisiatif. Tingkat inisiatif selama melaksanakan tugas pekerjaan khususnya dalam hal penanganan masalah-masalah yang timbul. (4) Kecekatan mental. Tingkat kemampuan dan kecepatan dalam menerima instruksi kerja, dan menyesuaikan dengan cara kerja serta situasi kerja yang ada. (5) Sikap. Tingkat semangat kerja serta sikap positif dalam melaksanakan tugas pekerjaan. (6) Disiplin waktu dan absensi. Tingkat ketepatan waktu dan tingkat kehadiran.

Faktor-faktor yang mempengaruhi promosi jabatan menurut (Simamora 2010) yaitu : (1) Kesempatan, Promosi jabatan di perusahaan harus memperhatikan kesesuaian antara latar belakang pendidikan dengan persyaratan jabatan yang ditetapkan oleh manajemen. (2) Kemampuan, Promosi jabatan di perusahaan harus dilakukan dengan mempertimbangkan pengalaman kerja dengan turut mempertimbangkan kreatifitas karyawan dalam bekerja. (3) Keadilan, Perusahaan harus melaksanakan promosi jabatan secara adil dengan memperhatikan kompetensi karyawan dan mempertimbangkan kinerja karyawan. (4) Prosedur, Promosi jabatan di perusahaan harus memiliki prosedur pelaksanaan yang baku dan dilakukan sesuai dengan prosedur.

Penyelesaian masalah promosi jabatan diperlukan pendekatan untuk mempertahankan karyawan terampil pendekatan yang digunakan adalah MSDM. Pendekatan tersebut menjelaskan salah satu sumber utama keunggulan kompetitif bagi suatu organisasi adalah karyawan (Imna dan Hassan, 2015:3). Promosi adalah salah satu motivasi yang terbaik bagi karyawan yang memiliki potensi maupun karyawan yang kurang berpotensi. Dengan promosi mereka akan terpicu untuk lebih sukses, namun dalam memberikan promosi ini, manajemen harus mengetahui mana yang terbaik dari peraturan yang telah ditetapkan.

Tujuan dari penelitian ini adalah untuk mengetahui gambaran dari disiplin kerja, prestasi kerja, dan promosi jabatan.

\section{KAJIAN PUSTAKA}

Suatu organisasi atau perusahaan peranan manajemen sumber daya manusia (SDM) sangatlah penting. Manusia merupakan penggerak dan pengelola faktor-faktor produksi lainnya seperti modal, bahan mentah, peralatan, dan lainlain untuk mencapai tujuan organisasi. Semakin berkembangnya suatu organisasi maka makin sulit pula perencanaan dan pengendalian pegawainya. Oleh karena itu, maka sangatlah dibutuhkan manajemen personalia yang mengatur dan mengatasi masalah-masalah yang berhubungan dengan kepegawaian, baik dalam hal administrasi, pembagian tugas maupun pada kegiatan personalia lainnya. Menurut Handoko (2011: 4) menjelaskan bahwa sumber daya manusia adalah penarikan, seleksi, pengembangan, pemeliharaan, dan penggunaan sumber daya manusia untuk mencapai baik tujuan-tujuan individu maupun organisasi.

Menurut Mondy (2012: 4) menjelaskan bahwa manajemen sumber daya manusia adalah pemanfaatan sejumlah individu untuk mencapai tujuan-tujuan organisasi. Sedangkan menurut Mathis dan Jackson (2013: 3) adalah rancangan sistem-sistem formal dalam sebuah organisasi untuk memastikan penggunaan bakat manusia secara efektif dan efisien guna mencapai tujuan organisasi.

Tujuan manajemen SDM adalah menyediakan tenaga kerja yang efektif bagi organisasi untuk mencapai tujuan yang telah ditetapkan sebelumnya (Rivai \& Sagala, 2013: 825). Dalam proses pencapaian tujuan ini, maka manajemen personalia mempelajari bagaimana memperoleh, mengembangkan, memanfaatkan, mengevaluasikan dan mempertahankan tenaga kerja dalam baik jumlah dan tipe yang tepat. Manajemen personalia dapat berhasil bila mampu menyediakan tenaga kerja yang berkompeten untuk melaksanakan pekerjaan yang harus dilakukan (Abdus Salam, 2014: 194).

Sumber Daya Manusia berperan dalam menciptakan pengaruh baik yang memungkinkan karyawan mendayagunakan kapasitas terbaik dan mewujudkan potensi karyawan demi kepentingan karyawan dan perusahaan. Manajemen SDM dibagi menjadi dua fungsi diantaranya fungsi manajerial dan fungsi operasional. Fungsi manajerial meliputi perencanaan (planning), pengorganisasian (organizing), pengarahan (directing), dan pengendalian (controlling). 
Kemudian fungsi operasional yaitu pengadaan tenaga kerja, pengembangan, kompensasi, pengintegrasian, pemeliharaan, dan pemutusan hubungan kerja Rivai dan Ella (2013:13)

Menurut Simamora (2012) disiplin adalah prosedur yang mengoreksi atau menghukum bawahan karena melanggar peraturan atau prosedur. Disiplin kerja adalah suatu alat yang digunakan para manajer untuk berkomunikasi dengan karyawan agar mereka bersedia untuk mengubah suatu perilaku serta sebagai suatu upaya untuk meningkatkan kesadaran dan kesediaan seseorang menaati semua peraturan perusahaan dan norma-norma sosial yang berlaku (Rivai, 2013). Indikator untuk mengukur variabel disiplin kerja pegawai dalam penelitian ini diadaptasi dari pendapat Veithzal Rivai (2014: 444), menjelaskan bahwa disiplin kerja memiliki beberapa komponen seperti:

1. Kehadiran. Hal ini menjadi indikator yang mendasar untuk mengukur kedisiplinan, dan biasanya karyawan yang memiliki disiplin kerja rendah terbiasa untuk terlambat dalam bekerja.

2. Ketaatan pada peraturan kerja. Karyawan yang taat pada peraturan kerja tidak akan melalaikan prosedur kerja dan akan selalu mengikuti pedoman kerja yang ditetapkan oleh perusahaan.

3. Ketaatan pada standar kerja. Hal ini dapat dilihat melalui besarnya tanggung jawab karyawan terhadap tugas yang diamanahkan kepadanya.

4. Tingkat kewaspadaan tinggi. Karyawan memiliki kewaspadaan tinggi akan selalu berhati-hati, penuh perhitungan dan ketelitian dalam bekerja, serta selalu menggunakan sesuatu secara efektif dan efisien.

5. Bekerja etis. Beberapa karyawan mungkin melakukan tindakan yang tidak sopan ke pelanggan atau terlibat dalam tindakan yang tidak pantas. Hal ini merupakan salah satu bentuk tindakan indisipliner, sehingga bekerja etis sebagai salah satu wujud dari disiplin kerja karyawan.

Menurut (Fathoni, 2012) kedisiplinan terdapat 6 aspek yang terkandung dalam disiplin kerja, yaitu

1. Tujuan dan kemampuan.

2. Keteladanan pimpinan

3. Keadilan

4. Waskat merupakan tindakan nyata dan paling efektif untuk mewujudkan kedisiplinan karyawan. Atasan harus aktif dan langsung mengawasi perilaku, moral, gairah kerja dan prestasi kerja bawahannya. Hal ini berarti atasan harus selalu hadir di tempat kerjanya agar dapat mengawasi dan memberikan petunjuk, jika ada bawahannya yang mengalami kesulitan.

5. Sanksi hukuman.

6. Ketegasan

Menurut (Muchadarsyah Sinungan, 2013) disiplin kerja memiliki sejumlah dimensi yakni:

1. Absensi; yakni pendataan kehadiran pegawai yang sekaligus merupakan alat untuk melihat sejauh mana pegawai itu mematuhi peraturan yang berlaku dalam perusahaan.

2. Sikap dan Perilaku; yakni tingkat penyesuaian diri seorang pegawai dalam melaksanakan semua tugas-tugas dari atasannya.

3. Tanggung Jawab; yakni hasil atau konsekuensi seorang pegawai atas tugastugas yang diserahkan kepadanya.

Berdasarkan penjelasan oleh para ahli mengenai indikator disiplin kerja

Menurut Setiyawan dan Waridin (2013) diantaranya, Kompensasi yang diperlukan meliputi: saran, arahan atau perbaikan, Kualitas kedisiplinan kerja, meliputi datang dan pulang yang tepat waktu, pemanfaatan waktu untuk pelaksanaan tugas dan kemampuan, mengembangkan potensi diri berdasarkan motivasi yang positif, Konservasi aturan meliputi penghormatan terhadap aturan dengan, keberanian untuk selalu melakukan pencegahan terjadinya tindakan yang, bertentangan dengan aturan, Kuantitas pekerjaan meliputi volume keluaran dan kontribusi dan Lokasi tempat kerja atau tempat tinggal.

Prestasi kerja ini pada dasarnya merupakan salah satu faktor kunci guna mengembangkan suatu perusahaan secara efektif dan efisien. Penilaian prestasi kerja juga memungkinkan para karyawan untuk mengetahui bagaimana prestasi kerja mereka, dan sejauh mana hasil kerja mereka dinilai oleh atasan. Maka dari itu, perlu diketahui terlebih dahulu mengenai pengertian prestasi kerja.

Prestasi kerja yang (Kusryanto 2013: 250) adalah perbandingan hasil yang dicapai dengan peran serta tenaga kerja persatuan waktu. Sedangkan menurut Dharma (dalam Ruki, 2012: 121) mengemukakan bahwa prestasi kerja adalah suatu yang Ruki (2012: 121) mengatakan bahwa dalam prestasi kerja tercakup hasil, prestasi kerja ditentukan oleh interaksi antara kemampuan dan motivasi.

Pengertian tentang prestasi dapat lebih mudah dipahami, disini dikemukakan beberapa pendapat, menurut Mangkunegara (2013: 67) adalah hasil kerja secara kualitas dan kuantitas yang dicapai oleh seseorang pegawai dalam melaksanakan tugasnya sesuai dengan tanggungjawab yang diberikan kepadanya. Pengertian penilaian prestasi kerja menurut Byars dan Rue (2011: 251) adalah: Performance appraisal is a process of determining 
and communicating to an employee how he or she is performing on the job, and ideally, establishing a plan of improvement (prestasi kerja karyawan adalah proses untuk menentukan dan mengkomunikasikan kepada karyawan tentang bagaimana performanya dalam melakukan pekerjaannya dan idealnya, membuat rencana untuk membangun kariernya).

Sesuai dengan pemaparan tersebut, maka dapat disimpulkan bahwa penilaian prestasi kerja adalah prestasi kerja (kinerja) secara kualitas dan kuantitas yang dicapai seseorang dalam melakukan tugas-tugas yang dibebankan kepadanya sebagai pembuatan rencana untuk membangun kariernya. Berdasarkan uraian tersebut, maka pelaksanaan penilaian prestasi di dalam suatu organisasi sangatlah penting. Karena dengan penilaian prestasi pihak manajemen dapat mengetahui tindakan-tindakan apa yang dapat dilakukan untuk meningkatkan keterampilan dan mengembangkan karyawannya, sesuai dengan potensi dan keterampilan dari karyawan tersebut. Sehingga dengan mengetahui hasil kerja merupakan alat ukur untuk mengetahui apakah proses rekrutmen dan seleksi serta penempatannya telah sesuai dengan efektivitas kerja atau tidak.

Prestasi kerja yang (Kusryanto 2013: 250) adalah perbandingan hasil yang dicapai dengan peran serta tenaga kerja persatuan waktu. Sedangkan menurut Dharma (dalam Ruki, 2012: 121) mengemukakan bahwa prestasi kerja adalah suatu yang Ruki (2012: 121) mengatakan bahwa dalam prestasi kerja tercakup hasil, prestasi kerja ditentukan oleh interaksi antara kemampuan dan motivasi. Flippo (2002) prestasi kerja seseorang dapat diukur melalui :

1. Mutu kerja, berkaitan dengan ketepatan waktu, keterampilan dan kepribadian dalam melakukan pekerjaan.

2. Kualitas kerja, berkaitan dengan pemberian tugas-tugas tambahan yang diberkan oleh atasan kepada bawahannya.

3. Ketangguhan, berkaitan dengan tingkat kehadiran, pemberian waktu libur, dan jadwal keterlambatan hadir di tempat kerja.

4. Sikap, merupakan sikap yang ada pada pegawai yang menunjukkan seberapa jauh tingkat kerja sama dalam menyelesaikan pekerjaan

5. Pemaparan yang telah dijelaskan maka indikator penilaian prestasi kerja

Para ahli telah banyak mempublikasikan pengertian tentang promosi. Menurut Siagian (2012:169), promosi jabatan adalah "pemindahan pegawai/karyawan, dari satu jabatan/tempat kepada jabatan/tempat lain yang lebih tinggi serta diikuti oleh tugas, tanggung jawab dan wewenang yang lebih tinggi dari jabatan yang diduduki sebelumnya”. Menurut Wahyudi (2012: 167) menyebutkan sebagai berikut :
1. Kejujuran
2. Loyalitas
3. Tingkat pendidikan
4. Pengalaman kerja
5. Rasa tanggung jawab
6. Kepemimpinan
7. Kerjasama
8. Inisiatif

\section{METODE PENELITIAN}

Penelitian ini dilakukan untuk mengetahui pengaruh disiplin kerja dan prestasi kerja terhadap promosi jabatan karyawan PT Telkom Indonesia Bandung. Adapun independet variable (variabel bebas) adalah disiplin kerja (X1) yang terdiri dari kehadiran, ketaatan pada peraturan kerja, ketaatan pada standar kerja, tingkat kewaspadaan tinggi dan bekerja etis, kemudian prestasi kerja (X2) yang terdiri dari kualitas kerja, kuantitas kerja, disiplin kerja, inisiatif dan kerjasama. Sedangkan yang menjadi dependent variable (variabel terikat) adalah promosi jabatan yang terdiri dari komponen pendidikan formal, pengalaman kerja, sikap atasan, prestasi kerja, adanya lowongan jabatan dan produktivitas kerja.

Berdasarkan penelitian ini yang menjadi objek penelitian adalah PT Telkom Indonesia Bandung sedangkan yang dijadikan sebagai unit analisis yaitu karyawan HRD PT Telkom Indonesia Bandung yang berlokasi di Jl. Japati No. 1 Bandung. Kemudian unit analisis yang dijadikan sebagai responden adalah karyawan HRD PT Telkom Indonesia. Penelitian ini akan dilakukan pada kurun waktu kurang dari satu tahun di tahun 2017, maka metode penelitian yang digunakan adalah cross sectional method. Sebagaimana yang dikemukakan oleh Creswell (2012:217), "Cross sectional survei yaitu survei yang dilakukan dengan mengumpulkan data satu persatu dalam satu waktu". Sehingga penelitian ini merupakan one shoot atau cross sectional. Berdasarkan variabel-variabel yang diteliti maka jenis penelitian ini adalah penelitian deskriptif dan verifikatif. Menurut Zainal Arifin (2011:41) menjelaskan penelitian deskriptif yaitu,"Penelitian yang dilakukan untuk menggambarkan (to describe), menjelaskan, dan menjawab persoalan-persoalan tentang fenomena dan peristiwa yang terjadi saat ini, baik tentang fenomena sebagaimana adanya maupun analisis hubungan antara berbagai fenomena suatu fenomena". Penelitian deskriptif ini mempunyai maksud mengetahui gambaran secara keseluruhan mengenai pengaruh disiplin kerja dan penilaian prestasi kerja terhadap promosi jabatan. Sedangkan penelitian verifikatif dimaksudkan untuk menguji kebenaran dari suatu hipotesis yang dilaksanakan melalui pengumpulan 
data di lapangan. Penelitian verifikatif ini untuk menguji pengaruh disiplin kerja dan penilaian prestasi kerja terhadap promosi jabatan PT Telkom Indonesia Bandung.

Berdasarkan jenis penelitian tersebut yaitu penelitian deskriptif dan verifikatif yang dilaksanakan melalui pengumpulan data di lapangan, maka metode yang digunakan dalam penelitan ini adalah metode survey atau explanatory survey bertujuan untuk mengetahui hubungan antar variabel dengan cara pengujian hipotesis. Menurut Sugiyono (2013:12), yang dimaksud dengan metode survei adalah, "Metode yang digunakan untuk mendapatkan data dari tempat tertentu yang alamiah (bukan buatan), tetapi peneliti melakukan perlakuan dalam pengumpulan data, misalnya dengan mengedarkan angket, tes dan wawancara terstruktur".

Berdasarkan pengertian explanatory survey menurut ahli, maka metode penelitian ini dilakukan melalui kegiatan pengumpulan informasi dari sebagian populasi secara langsung di tempat kejadian (empirik) dengan tujuan untuk mengetahui pendapat dari sebagian populasi terhadap objek yang sedang diteliti

Variabel penelitian ini adalah kompetensi karyawan, penilaian prestasi kerja, dan promosi jabatan. Secara teoritis, definisi operasionalisasi variabel adalah unsur penelitian yang memberikan penjelasan atau keterangan tentang variabelvariabel operasionalisasi sehingga dapat diamati atau diukur sebagai berikut :

1. Variabel independent adalah Disiplin kerja (X1) dan Prestasi Kerja (X2)

2. Variabel dependent adalah Y (Promosi jabatan) Jenis data merupakan informasi tentang segala sesuatu yang berkaitan dengan variabel yang diteliti. Oleh karena itu harus diproses terlebih dahulu untuk memperoleh informasi yang diperlukan bagi suatu penelitian. Jenis data dalam penelitian ini terdiri dari data tentang karakteristik umum PT Telkom Indonesia Bandung beserta data masing-masing variabel yang dikaji. Sedangkan sumber data yang digunakan ada dua, yaitu data primer dan data sekunder. Burhan Bungin (2013:128) data primer adalah data yang diambil dari sumber data utama dilapangan.

Data sekunder menurut Sangadji dan Sopiah (2010:190) adalah "Data yang diterbitkan atau digunakan oleh organisasi yang bukan pengolahnya". Untuk penelitian primer dapat diperoleh melalui hasil penelitian secara empirik melalui penyebaran kuisioner kepada karyawan HRD PT Telkom Indonesia Bandung sebagai responden. Sedangkan sumber data sekunder diantaranya diperoleh dari jurnal-jurnal ilmiah, artikel majalah, internet dan berbagai sumber informasi lainnya. Kegiatan pengumpulan data merupakan langkah penting untuk mengetahui karakteristik dari populasi yang merupakan elemen-elemen dalam objek penelitian. Data yang dikumpulkan digunakan untuk mengambil keputusan dalam menguji hipotesis. Sugiyono (2013:119) menjelaskan bahwa, "Populasi adalah wilayah generalisasi yang terdiri atas subjek/objek yang mempunyai kualitas dan karakteristik tertentu, yang ditetapkan oleh peneliti untuk dipelajari dan kemudian ditarik kesimpulannya".

Populasi bukan hanya orang tetapi juga obyek dan benda-benda alam yang lain. Populasi juga bukan sekedar jumlah yang ada pada obyek/subyek yang dipelajari, tetapi meliputi seluruh karakteristik atau sifat yang dimiliki oleh subyek atau obyek itu. Berdasarkan pengertian populasi menurut ahli, maka populasi dalam penelitian ini adalah karyawan HRD PT Telkom Indonesia Bandung dengan jumlah 96 orang (Admin HR PT. Telkom Indonesia Bandung). Menurut Sugiyono (2011:81), "Sampel adalah bagian dari jumlah dan karakteristik yang dimiliki oleh populasi tersebut". Selain itu sampel yang akan dipilih harus representatif artinya segala karakteristik populasi hendaknya tercermin dalam sampel yang dipilih. penelitian ini menggunakan sampel jenuh. Istilah lain sampel jenuh adalah sensus, dimana semua anggota populasi dijadikan sampel. Berdasarkan pendapat di atas, dikarenakan jumlah karyawan PT Telkom Indonesia Bandung kurang dari 100 orang, maka sampel yang diambil adalah seluruh jumlah populasi atau jumlah karyawan HRD PT Telkom Indonesia Bandung sebanyak 96 orang. Teknik pengumpulan data adalah cara yang digunakan untuk mengumpulkan data yang diperlukan. Sumber data yang diperlukan dalam penelitian ini di dapat dengan menggunakan beberapa teknik pengumpulan data sebagai berikut :

1.Studi kepustakaan yaitu dilakukan untuk memperoleh data sekunder yang akan digunakan menjadi landasan teori masalah yang diteliti. Dalam kepustakaan ini penulis membaca dan mempelajari buku-buku, literatur, internet dan materi yang berhubungan dengan masalah yang diteliti. Hal tersebut ditujukkan untuk memperoleh informasi serta gambaran yang jelas mengenai masalah yang diteliti.

2.Angket merupakan teknik pengumpulan data yang dilakukan dengan cara memberi seperangkat pernyataan tertulis kepada responden untuk dijawabnya (Sugiyono, 2013:199). Angket yang akan penulis sebarkan berisi pertanyaan atau pernyataan yang dapat dijadikan sebagai pengukuran dari indikator-indikator baik variabel X1 (disiplin kerja), X2 (prestasi kerja) dan variabel $\mathrm{Y}$ (promosi jabatan) yang ditujukan untuk sebagian karyawan PT Telkom Indonesia Bandung. Langkah-langkah yang ditempuh dalam penyusunan angket antara lain :

a. Menyusun kisi-kisi angket atau daftar 
pertanyaan.

b. Merumuskan item-item pertanyaan dan alternatif jawaban. Jenis instrumen yang digunakan dalam angket merupakan instrumen yang bersifat tertutup, yaitu seperangkat alat tulis dan disertai dengan alternatif jawaban yang disediakan, sehingga responden hanya memilih jawaban yang tersedia.

c. Menetapkan pemberian skor untuk setiap item pertanyaan. Pada penelitian ini setiap pendapat responden atas pertanyaan diberi nilai dengan skala.

3. Observasi, yaitu pengamatan dan peninjauan langsung terhadap objek yang sedang diteliti khususnya mengenai disiplin kerja dan penilaian prestasi kerja terhadap promosi jabatan karyawan HRD PT. Telkom Indonesia Bandung

4. Wawancara, yaitu pengumpulan data atau informasi melalui komunikasi langsung kepada pihak-pihak yang berkepentingan atau terkait yang dapat memberikan keterangan-keterangan dan data yang diperlukan, dalam hal ini adalah karyawan HRD PT Telkom Indonesia Bandung.

\section{HASIL PENELITIAN DAN PEMBAHASAN}

Hasil pengolahan data yang dilakukan melalui penyebaran angket pada karyawan PT. Telkom Indonesia Bandung, disiplin dapat diukur melalui perhitungan rata-rata dimensi dan perhitungan skor keseluruhan. Berikut ini dipaparkan hasil dari rekapitulasi perhitungan skor.

TABEL 4. 1

REKAPITULASI DIMENSI DISIPLIN

\begin{tabular}{|c|c|c|c|c|}
\hline No & Dimensi & $\begin{array}{l}\text { Total } \\
\text { Skor }\end{array}$ & $\begin{array}{l}\text { Skor } \\
\text { Ideal }\end{array}$ & $\%$ \\
\hline \multicolumn{5}{|c|}{ Disiplin } \\
\hline 1 & Kehadiran & 2559 & 3360 & $76,1 \%$ \\
\hline 2 & $\begin{array}{l}\text { Ketaatan pada } \\
\text { peraturan kerja }\end{array}$ & 1909 & 2704 & $70,5 \%$ \\
\hline 3 & $\begin{array}{l}\text { Ketaatan pada } \\
\text { Standar kerja }\end{array}$ & 1436 & 2016 & $71,2 \%$ \\
\hline 4 & $\begin{array}{l}\text { Tingkat } \\
\text { Kewaspadaan } \\
\text { tinggi }\end{array}$ & 1578 & 2016 & $78,2 \%$ \\
\hline $\begin{array}{l}5 \\
\text { Tot }\end{array}$ & Bekerja Etis & $\begin{array}{l}1133 \\
\mathbf{8 6 1 5}\end{array}$ & $\begin{array}{c}1344 \\
\mathbf{1 1 4 4 0}\end{array}$ & $\begin{array}{l}84,3 \% \\
\mathbf{7 5 , 4 \%}\end{array}$ \\
\hline
\end{tabular}

Sumber : Hasil Pengolahan Data 2018

Berdasarkan tabel 4.25 hasil penelitian dari angket yang disebar kepada 96 responden dapat diketahui bahwa disiplin kerja karyawan HRD PT. Telkom Indonesia Bandung mencapai skor 8615 dari skor kriterium atau jumlah maksimal perolehan nilai responden terletak pada daerah efektif yaitu pada interval 7227,2-8626, dimana nilai terendah dari garis kontinum disiplin kerja yaitu 1632 dan nilai tertinggi garis kontinumnya sebesar 11424. Skor tertinggi berdasarkan hasil jawaban responden terdapat pada kehadiran memperoleh skor sebanyak 2559 atau $76,1 \%$ dari skor ideal. Dalam hal ini perusahaan sudah cukup efektif dalam menerapkan aturan disiplin kerja, Sehingga pemimpin bisa dengan mudah bekerjasama dengan karyawan untuk bisa mencapai tujuan organisasi.

Sementara skor terendah terdapat pada dimensi kehadiran yaitu dimensi ketaatan pada peraturan kerja memperoleh skor 1909 atau $70.9 \%$. dari skor ideal. Ketaatan pada saat bekerja hal ini dapat dilihat melalui besarnya tanggung jawab karyawan terhadap tugas yang diamanahkan kepadanya. Setiap orang maupun perusahaan dalam melakukan kegiatan selalu berusaha untuk menentukan metode kerja yang baik, karena dengan metode kerja yang baik akan dapat meningkatkan produkvitas kerja yang tinggi (Mulyana, 2005: 103).

Skor ideal disiplin kerja adalah 11440 untuk 17 item pertanyaan. Perolehan skor berdasarkan hasil pengolahan data pada variabel komunikasi kerja adalah 8615. Sedangkan untuk mencari daerah kontinum yang menunjukkan wilayah ideal dari tanggapan responden terhadap disiplin kerja, berdasarkan rumus Sugiyono (2013:94) adalah sebagai berikut :

Mencari Skor Ideal Disiplin Kerja

Skor Ideal $=$ Skor Tertinggi $\mathrm{X}$

Jumlah Butir Item X Jumlah Responden

$$
\text { Skor Ideal } \quad=7 \times 17 \times 96=11424
$$

Mencari Skor Minimum Disiplin

Skor Minimum = Skor Terendah $\mathrm{X}$

Jumlah Butir Item X Jumlah Responden

$$
\text { Skor Minimum } \quad=1 \times 17 \times 96=1632
$$

Mencari Panjang Interval

Panjang Interval Kelas $=($ Skor Ideal - Skor Minimum $) \div$ Banyak Interval

Panjang Interval Kelas $=(11424-1632) \div 7$

$=1398,8$

Mencari Persentase Skor

$\begin{aligned} & \text { Persentase Skor } \\ & \text { Nilai Maksimum }] \text { x 100\% }\end{aligned}=[$ (Total Skor $)$ :

Persentase Skor $\quad=[(8615): 11424]$

$\mathrm{x} 100 \%=75,4 \%$

Skor ideal disiplin kerja adalah 11424 untuk 17 item pernyataan. Perolehan skor berdasarkan hasil pengolahan dari variabel disiplin kerja adalah 8615 atau $75,4 \%$, skor tersebut secara kontinum dapat digambarkan sebagai berikut.

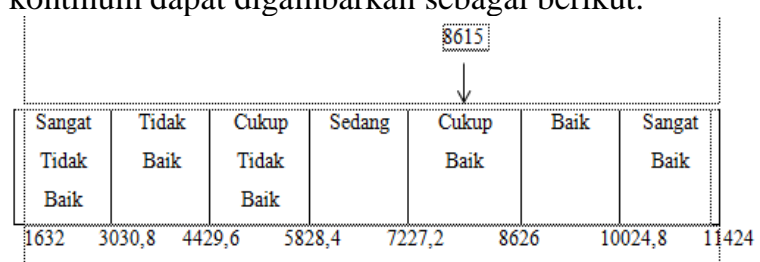


Sumber : Hasil Pengolahan Data 2018

GAMBAR 4. 1

GARIS KONTINUM VARIABEL DISIPLIN

Berdasarkan Gambar 4.3 nilai kontinum disiplin dari angket yang disebar kepada 96 responden diketahui bahwa disiplin karyawan PT. Telkom Indonesia Bandung mencapai skor 8615 dari skor kriterium atau jumlah maksimal perolehan nilai responden terletak pada daerah efektif yaitu pada interval 7227,2-8626 sehingga dapat dikatakan bahwa dalam penelitian ini disiplin yang dimiliki karyawan PT. Telkom Indonesia Bandung telah diaplikasikan dengan cukup baik, akan tetapi disiplin tersebut masih perlu ditingkatkan lagi, karena semua dimensi berada di bawah skor ideal.

Berdasarkan hasil pengolahan data yang dilakukan melalui penyebaran angket pada karyawan HRD PT. Telkom Indonesia Bandung, prestasi kerja karyawan dapat diukur melalui perhitungan rata-rata dimensi dan perhitungan skor keseluruhan. Berikut ini dipaparkan hasil dari rekapitulasi perhitungan skor:

TABEL 4. 2

\section{REKAPITULASI DIMENSI PRESTASI} KERJA KARYAWAN

\begin{tabular}{ccccc}
\hline \multirow{2}{*}{ No. } & Dimensi & $\begin{array}{c}\text { Total } \\
\text { Skor }\end{array}$ & $\begin{array}{c}\text { Skor } \\
\text { Ideal }\end{array}$ & \multirow{2}{*}{$\%$} \\
\hline \multicolumn{2}{l}{ Prestasi Kerja } & & & \\
\hline 1. & Mutu kerja & 1640 & 2016 & $81,3 \%$ \\
2. & Kualitas kerja & 1596 & 2016 & $79,1 \%$ \\
3. & Ketangguhan & 1915 & 2688 & $71,2 \%$ \\
4. & Sikap Kerja & 1570 & 2016 & $77,8 \%$ \\
\hline \multicolumn{6}{c}{ Total } & $\mathbf{6 7 2 1}$ & $\mathbf{8 7 3 6}$ & $\mathbf{7 6 , 9 \%}$ \\
\hline
\end{tabular}

Sumber : Hasil Pengolahan Data 2018

Berdasarkan Tabel 4.26 hasil penelitian dari angket yang disebar kepada 96 responden dapat diketahui bahwa prestasi kerja karyawan HRD PT. Telkom Indonesia Bandung mencapai skor 6721 dari skor kriterium atau jumlah maksimal perolehan nilai responden terletak pada daerah efektif yaitu 6596,55-7666,26, dimana nilai terendah garis kontinum prestasi kerja yaitu 1248 dan nilai tertinggi garis kontinumnya sebesar 8736 . Skor tertinggi terdapat pada dimensi mutu kerja memperoleh skor sebanyak 1640 atau $81,3 \%$ dari skor ideal. Artinya, karyawan sudah merasa puas dengan mutu kerja yang diberikan perusahaan karena sudah sesuai dengan pekerjaan yang diberikan oleh atasan. karyawan dituntut untuk memiliki tanggung jawab terhadap pekerjaannya. Selain itu, setiap pekerjaan memerlukan keterampilan tertentu sesuai dengan bidangnya masing-masing. inti dari mutu kerja adalah suatu hasil yang dapat diukur dengan efektifitas dan efisiensi suatu pekerjaan yang dilakukan oleh sumber daya manusia atau sumber daya lainnya dalam pencapaian tujuan atau sasaran perusahaan dengan baik dan berdaya guna (Flippo 2002 : 28).
Sedangkan untuk skor terendah yaitu pada dimensi ketangguhan yang memperoleh skor 1915 atau $71,2 \%$ dari skor ideal. Hal tersebut dikarenakan pemberian waktu cuti seharusnya diatur secara jelas oleh perusahaan untuk memberikan kejelasan kepada karyawan mengenai karyawan yang boleh mengambil cuti dengan gaji tetap dibayar. Termasuk mengenai cuti tambahan ketika karyawan tidak bisa datang bekerja karena sakit. Pada dasarnya ini kembali pada kesepakatan antara perusahaan dengan karyawan untuk memberlakukan cuti sakit ke dalam cuti tahunan atau tidak sehingga dengan hal tersebut karyawan merasa tidak puas.

Skor ideal prestasi kerja karyawan adalah 8736 untuk 13 item pernyataan.

Perolehan skor berdasarkan hasil pengolahan data pada variable prestasi kerja karyawan adalah 6721 sedangkan untuk mencari daerah kontinum yang menunjukan wilayah ideal dari tanggapan responden terhadap prestasi kerja karyawan, berdasarkan rumus Sugiyono (2011:94) adalah sebagai berikut:

Mencari Skor Ideal Prestasi Kerja

Skor Ideal = Skor Tertinggi $\mathrm{X}$

Jumlah Butir Item X Jumlah Responden

Skor Ideal $=7$ X 13 X 96

$$
=8736
$$

Mencari Skor Minimum Prestasi Kerja Karyawan

Skor Minimum $=$ Skor Terendah $\mathrm{X}$

Jumlah Butir Item X Jumlah Responden

Skor Minimum $\quad=1$ X 13 X 96

$$
=1248
$$

Mencari Panjang Interval

Panjang Interval Kelas $=($ Skor Ideal - Skor Minimum $) \div$ Banyak Interval

Panjang Interval Kelas $=(8736-1248) \div 7$

$$
=1069,71
$$

Mencari Persentase Skor

$\begin{array}{lcc}\text { Persentase Skor } & = & {[(\text { Total }} \\ \text { Skor }) \div \text { Nilai Maksimum }] \times 100 \% & \\ \text { Persentase Skor } & = & {[(6721) \div} \\ 8736] \times 100 \% & & \end{array}$

$$
=76,9 \%
$$

Skor ideal prestasi kerja karyawan adalah 8736 untuk 13 item pernyataan. Perolehan skor berdasarkan hasil pengolahan dari variabel prestasi kerja karyawan adalah 6721 atau 76,9\%, skor tersebut secara kontinum dapat digambarkan sebagai berikut:

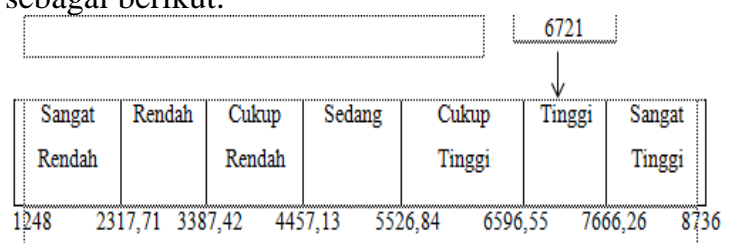

Sumber : Hasil Pengolahan Data 2018 


\section{GAMBAR 4. 2 GARIS KONTINUM VARIABEL PRESTASI KERJA KARYAWAN}

Berdasarkan Gambar 4.4 pada nilai kontinum dari angket yang disebar kepada 96 responden dapat diketahui bahwa prestasi kerja karyawan HRD PT. Telkom Indonesia Bandung mencapai skor 6721 dari skor kriterium atau jumlah maksimal perolehan nilai responden terletak pada daerah 6596,55-7666,26 sehingga dapat dikatakan bahwa dalam penelitian ini prestasi kerja yang dimiliki karyawan HRD PT. Telkom Indonesia Bandung memiliki prestasi kerja tinggi dan masih perlu ditingkatkan lagi karena semua dimensi berada dibawah skor ideal.

Berdasarkan hasil pengolahan data yang dilakukan melalui penyebaran angket pada karyawan HRD PT. Telkom Indonesia Bandung, promosi jabatan karyawan dapat diukur melalui perhitungan rata-rata dimensi dan perhitungan skor keseluruhan. Berikut ini dipaparkan hasil dari rekapitulasi perhitungan skor:

TABEL 4. 3

\section{REKAPITULASI DIMENSI PROMOSI} JABATAN

\begin{tabular}{ccccc}
\hline No & Dimensi & $\begin{array}{c}\text { Total } \\
\text { Skor }\end{array}$ & $\begin{array}{c}\text { Skor } \\
\text { Ideal }\end{array}$ & $\%$ \\
\hline Promosi Jabatan & & & \\
\hline 1 & Pendidikan & 1515 & 2016 & $75,1 \%$ \\
2 & Pengalaman & 1629 & 2016 & $80,8 \%$ \\
3 & Loyalitas & 2050 & 2688 & $76,2 \%$ \\
4 & Kerjasama & 1620 & 2016 & $80,3 \%$ \\
& Karyawan & & & \\
\hline \multicolumn{6}{c}{ Total } & $\mathbf{6 8 1 4}$ & $\mathbf{8 7 3 6}$ & $\mathbf{7 7 , 9 \%}$ \\
\hline
\end{tabular}

Sumber : Hasil Pengolahan Data 2018

Berdasarkan Tabel 4.27 aspek promosi jabatan hasil melalui penelitian angket yang disebar, diperoleh skor tertinggi terdapat pada dimensi pengalaman memperoleh skor sebanyak 1629 atau $80,8 \%$ dari skor ideal, yang artinya pengalaman karyawan dalam bekerja sudah tinggi, karyawan mampu menyelesaikan pekerjaan sesuai dengan target yang ditentukan oleh perusahaan. Namun terkadang karyawan masih belum rapih dalam menyelesaikan pekerjaan nya seperti pada pembutan laporan kerja. Proses pembentukan pengetahuan atau keterampilan tentang metode suatu pekerjaan karena keterlibatan karyawan tersebut dalam pelaksanaan tugas pekerjaan. Pengalaman kerja adalah ukuran tentang lama waktu atau masa kerja yang telah ditempuh seseorang dapat memahami tugas - tugas suatu pekerjaan dan telah melaksanakan dengan baik.

Sedangkan untuk skor terendah yaitu pendidikan yang memperoleh skor 1515 atau $75,1 \%$ dari skor ideal. Hal tersebut dikarenakan pendidikan di perusahaan PT. Telkom masih rendah dan belum berjalan efektif, terdapat beberapa karyawan yang masih berpendidikan lulusan SMA/SMK pendidikan sebagai usaha sadar dan terencana untuk mewujudkan suasana bekerja dan belajar untuk karyawan secara aktif mengembangkan potensi dirinya untuk memiliki kekuatan spiritual keagamaan, pengendalian diri, kepribadian, kecerdasan, akhlak mulia, serta keterampilan yang diperlukan dirinya dan masyarakat..

Skor ideal promosi jabatan karyawan adalah 8736 untuk 13 item pernyataan Perolehan skor berdasarkan hasil pengolahan data pada variabel promosi jabatan adalah 6814 sedangkan untuk mencari daerah kontinum yang menunjukan wilayah ideal dari tanggapan responden terhadap promosi jabatan, berdasarkan rumus Sugiyono (2011:94) adalah sebagai berikut:

Mencari Skor Ideal Promosi Jabatan Karyawan

$$
\begin{aligned}
& \text { Skor Ideal = Skor Tertinggi X } \\
& \text { Jumlah Butir Item X Jumlah Responden } \\
& \text { Skor Ideal } \quad=7 \text { X } 13 \text { X } 96 \\
& =8736
\end{aligned}
$$

Mencari Skor Minimum Promosi Jabatan Karyawan

Skor Minimum = Skor Terendah X

Jumlah Butir Item X Jumlah Responden

Skor Minimum $\quad=1$ X 13 X 96 $=1248$

Mencari Panjang Interval

Panjang Interval Kelas $=($ Skor Ideal - Skor

Minimum $) \div$ Banyak Interval

Panjang Interval Kelas $=(8736-1246) \div 7$

$$
=1070
$$

Mencari Persentase Skor

$$
\text { Persentase Skor = } \quad[\text { Total }
$$

Skor $) \div$ Nilai Maksimum] x $100 \%$

$$
\begin{array}{ll}
\text { Persentase Skor } & =[(6814) \div \\
8736] \times 100 \% & =77,9 \%
\end{array}
$$

Skor ideal promosi jabatan karyawan adalah 8736 untuk 13 item pernyataan. Perolehan skor berdasarkan hasil pengolahan dari variabel promosi jabatan karyawan adalah 6814 atau 77,9\%, skor tersebut secara kontinum dapat digambarkan sebagai berikut:

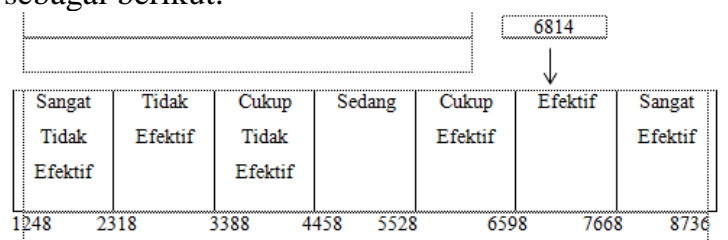

Sumber : Hasil Pengolahan Data 2018

GAMBAR 4. 3

\section{GARIS KONTINUM VARIABEL PROMOSI} JABATAN

Berdasarkan Gambar 4.5 pada nilai kontinum variabel promosi jabatan karyawan yaitu 6814 sesuai dengan data penelitian yaitu termasuk kedalam kategori efektif, dengan demikian dapat dikatakan bahwa karyawan memiliki promosi 
jabatan yang efektif, akan tetapi promosi jabatan karyawan pada perusahaan masih perlu ditingkatkan karena semua dimensi berada di bawah skor ideal. Dari angket yang disebar kepada 96 responden dapat diketahui bahwa promosi jabatan karyawan PT. Telkom Indonesia Bandung mencapai skor 6814 dari skor kriterium atau jumlah maksimal perolehan nilai responden terletak pada daerah 6598-7668, dimana nilai terendah garis kontinum promosi jabatan karyawan yaitu 1248 dan nilai tertinggi garis kontinumnya sebesar 8736 . Sehingga dapat dikatakan bahwa dalam penelitian ini promosi jabatan yang dimiliki karyawan HRD. PT. Telkom Indonesia Bandung sudah efektif , namun promosi jabatan karyawan masih perlu ditingkatkan lagi karena semua dimensi berada dibawah skor ideal.

\section{KESIMPULAN DAN REKOMENDASI}

Berdasarkan hasil penelitian yang telah dilakukan menggunakan analisis deskriptif dengan distribusi frekuensi dapat diambil kesimpulan bahwa gambaran disiplin kerja dalam kategori cukup baik, gambaran prestasi kerja dalam kategori tinggi dan promosi jabatan dalam kategori tinggi.

Adanya penelitian ini diharapkan dapat membantu peneliti berikutnya dalam melakukan penelitian mengenai disiplin kerja, prestasi kerja, dan promosi jabatan dengan menggunkan indikator yang berbeda dari sumber teori yang lebih beragam, dan terhadap objek yang berbeda, karena masih banyaknya keterbatasan dalam penelitian ini, khususnya yang berkaitan dengan metode penelitian dan teknik pengumpulan data.

\section{DAFTAR PUSTAKA}

\section{BUKU}

A.A. Anwar Prambudu Mangkunegara. (2014). Manajemen Sumber Daya Manusiaperusahaan. Bandung: Remajarosdakarya.

Ali, M. (1985). Penelitian Pendidikan Prosedur Dan Strategi. Bandung: Angkasa.

Amstrong, M. (2010). Armstrong's Handbook Of Human Resorce Management Practice. United Kingdom: Kogan Page Limited (11th Ed.). New York.

Armstrong, M., 2012. Handbook of Human Resource Management Practice 12th ed., London: KoganPage.

Armstrong, M. \& Taylor, S., 2014. Armstrong's Handbook of Human Resource Management Practice 13th ed., London: KoganPage.

Ayu, R.S. \& Rachbini, D.J., 2014. Pengaruh Pemberdayaan Karyawan, Promosi Jabatan, Lingkungan terhadap Keputusan serta Dampaknya terhadap Retensi karyawan Kajian pada Region III PT. Permata Bank Tbk. , pp.1-21.
Bt Fauzi, N.F., Ahmad, F. \& Gelaidan, H.M., 2013. The Employee Retention Status in Paddy and Rice Industry in Malaysia. Middle-East Journal of Scientific Research, 18(5), pp.642-650.

Bungin, Burhan. 2013. Penelitian Kualitatif: Komunikasi, Ekonomi, Kebijakan Publik, dan Ilmu Sosial lainnya. Jakarta: Kenaca Prenada Media Group.

Bernson, M. L. Et. Al. (2012). Basic Business Statistics Concept And Aplication (12th Editi). Prentice Hall.

Civil Service Branch. (2013). Human Resource Management Civil Service Branch. Civil Service Branch, (December).

Colquitt, Jason A., Jeffery A.Lepine, \& M. J. W. (2011). Organizational Behavior. New York: Mcgraw-Hill.

Dessler. (2011). Fundamentals Of Human Resource Management. (Ipskamp, Ed.) (Third Edit). Groningen: African Studies Centre. Https://Doi.Org/2211-8284

Gibson,James L.,John M. Ivancevich, James H. Donnelly, Jr., \& R. K. (2012). Organization. New York: Mcgraw-Hill.

Gomez-Mejia, L. R. And D. B. B. And R. L. C. (2012). Managing Human Resources. Prentice Hall: Pearson Education, Inc.

Griffin, J. (2013). Costumer Loyalty How To Earn It,How To Keep It. Singapore: Lexingtonbooks.

Griffin, R., \& Moorhead, G. (2013). Organizational Behavior: Managing People And Organizations (Eleventh). SouthWestern Cengage Learning.

H. Hadari Nawari. (2013). Kepemimpinan Mengefektifan Organisasi. Yogyakarta: Gajahmadauniversitypress.

Heskett, J. L., Sasser, E. W., \& Wheeler, J. (2008). The Ownership Quotient: Putting The Service Profit Chain To Work For Unbeatable Competitive Advantage ( $(\mathrm{H} . \mathrm{B}$. Pre). Boston, Mass.

Hope, J. \& S. P. (2012). Beyond Performance Management. Boston: Harvard Business Reviev Press.

Kementrian Negara. (2012). Pedoman Pengembangan Budaya Kerja Aparatur Negara Oleh Kementrian Negara Pendayagunaanaparaturnegara.

\section{JURNAL}

Agyeman, C.M. \& Ponniah, V.M., 2014. Employee Demographic Characteristics and Their Effects on Turnover and Retention in MSMEs. International Journal of Recent Advances in Organzitional Behaviour and Decision Sciences, 1(1), pp.12-29.

Ahmad, N., Iqbal, N. \& Sheeraz, M., 2012. The Effect of Internal Marketing on Employee 
retention in Pakistani Banks. International journal of Academic Research in Business and Social Sciences, 2(8), pp.270-280. Available at: http://www.hrmars.com/admin/pics/1055.pd f.

Akila, R., 2012. A Study on Employee Retention among Executives at BGR Energy Systems LTD, Chennai. International Journal of Marketing, Financial Services \& Management Research, 1(9), pp.18-32.

Aktar, S., Sachu, M. \& Ali, M., 2012. The Impact of Rewards on Employee Performance in Commercial Banks of Bangladesh: An Empirical Study. IOSR Journal of Business and Management, 6(2), pp.9-15. Available at: http://iosrjournals.org/iosrjbm/papers/Vol6-issue2/B0620915.pdf.

Allen, D.G., 2008. Retaining Talent: A Guide to Analyzing and Managing Employee Turnover, US: SHRM Foundation. Available at:

http://www.shrm.org/about/foundation/resea $\mathrm{rch} /$ documents/retaining talent- final.pdf.

Anis, A. et al., 2011. Employee retention relationship to training and development: A compensation perspective. African Journal of Business Management, 5(7), pp.26792685.

$$
\text { Available }
$$

at: http://www.academicjournals.org/ajbm/pdf/ pdf2011/4Apr/Anis et al.pdf.

Ahmed, K. (2012). I Nterdisciplinary J Ournal O F C Ontemporary R Esearch I N B Usiness Impact Of Training On Employee Performance : A Study Of, 646-661.

Al-Tit, A., \& Hunitie, M. (2015). The Mediating Effect Of Employee Engagement Between Its Antecedents And Consequences. Journal Of Management Research, 7(5), 47. Https://Doi.Org/10.5296/Jmr.V7i5.8048

Allen, N. J., \& Meyer, J. P. (1990). The Measurement And Antecedents Of Affective, Continuance And Normative Commitment To The Organization. Journal Of Occupational Psychology, 63, 1-18. Https://Doi.Org/10.1111/J.20448325.1990.Tb00506.X

Ampomah, P. (2016). Asian Journal Of Social Sciences " The Effect Of Training And Development On Employee Performance In A Private Tertiar Y Institution In Ghana " ( Case Study: Pentecost University College ( Puc ) - Ghana ), 3(1), 29-33.

Andyani, N. \&. (2016). Fakultas Ekonomi Dan Bisnis Universitas Udayana ( Unud ), Bali , Indonesia Pendahuluan Perusahaan Merupakan Suatu Organisasi Yang Terdiri Atas Sekelompok Orang Yang Bekerja Untuk Mencapai Suatu Tujuan . Kepentingan
Yang Paling Mendasar Yaitu Mendapatkan $\mathrm{K}, 5(1), 500-532$.

Asamaranty, N. (2014). Pengaruh Kompensasi Dan Lingkungan Kerja Terhadap Kinerja Karyawan Divisi Lab Steel Plant Ii Direktorat Produksi Pt Krakatau Steel (Persero) Di Cilegon, 1-23.

Baruch, Y. (2011). The Positive Wellbeing Aspects Of Workaholism In Cross Cultural Perspective: The Chocoholism Metaphor. Career Development International, Vol 16(Issue 6), Pp.572-591. 